\title{
A RECONNAISSANCE IN THE CANYON RANGE, WEST-CENTRAL UTAH.
}

By G. F. Loughlin.

\section{INTRODUCTION.}

\section{PREVIOUS STUDIES IN THE REGION.}

The Canyon Range, in west-central Utah, which derives its name from the deep valley cut through its northern part by Sevier River, has hitherto received no general geologic study, not even of a reconnaissance nature. The atlas of the Wheeler Survey, ${ }^{1}$ though showing the geology of the surrounding ranges, leaves the Canyon Range blank. Gilbert, in his study of Lake Bonneville, ${ }^{2}$ examined the lake deposits in the valleys on the east and west sides of the range and in Sevier Canyon which connects them, but paid no special attention to the hard rocks of the range. Tower and Smith, ${ }^{3}$ in their report on the Tintic district, north of the Canyon Range, mention the presience of folded Paleozoic strata, including Carboniferous limestone; along Sevier Canyon, and of Eocene conglomerate resting unconformably upon the Paleozoic rocks. Their statement was based on observations made during a day's drive from Juab to Leamington by Smith, who noted the absence of volcanic material in the Eocene conglomerate and the abundance of it in the Pleistocene and recent alluvial deposits, and therefore concluded that the Tertiary volcanic rocks, which form the southern part of the Tintic Mountains, were postEocene. The latest geologic map of North America ${ }^{4}$ represents the Canyon Range as composed entirely of Cambrian and Lower Ordovician strata.

FIELD WORK.

The writer in $1912^{5}$ made a trip through Sevier Canyon, noting the unconformity between the Eocene conglomerate and the Paleozoic strata and also the presence of a bed of dark-colored volcanic rock, presumably andesite or latite, resting upon Eocene conglomerate, thus verifying Smith's conclusions. The close resemblance of the Paleozoic quartzite in general lithologic character to the Cambrian quartzite of the Tintic district, together with the age assigned to it on the geologic map of North America (just cited), led the writer to describe the Tertiary conglomerate as here resting on Cambrian quartzite. In June, 1913, however, while visiting the Leamington mining district, he took the opportunity to make a hasty reconnaissance of the range, spending half a day in the mountains north of Sevier Canyon and three days in trips up Wood, Yellowstone, Fool Creek, and Oak Creek canyons and along the west base of the range. It was found that the quartzite, instead of being Cambrian, rested in apparent conformity upon lower Mississippian limestone. No careful measurements of the thicknesses of these formations were attempted, but interesting structural data were gathered, which, though far from complete, are believed to be worthy of presentation.

1 U. S. Geog. Surveys W. 100th Mer., atlas sheet 50.

${ }^{2}$ Gilbert, G. K., Lake Bonneville: U. S. Geol. Survey Mon. 1, pp. 104, 166, 192, and 193, 1890.

3 Tower, G. W., and Smith, G. O., Geology and mining industry of the Tintic district, Utah: U. S. Geol. Survey Nineteenth Ann. Rept., pt. 3 , pp. 617,671 , and 673,1899 .

4 Willis, Bailey, Index to the stratigraphy of North America: U. S. Geol. Survey Prof. Paper 71, Pl. I, 1912.

${ }^{5}$ Loughlin, G. F., Reconnaissance in the southern Wasatch Mountains, Utah: Jour. Geology, vol. 21, p. 448, 1913. 


\section{TOPOGRAPHY.}

The Canyon Range, as shown on the accompanying map (fig. 4), has the general features of the maturely dissected basin ranges, but the transverse canyons on its west side are surprisingly
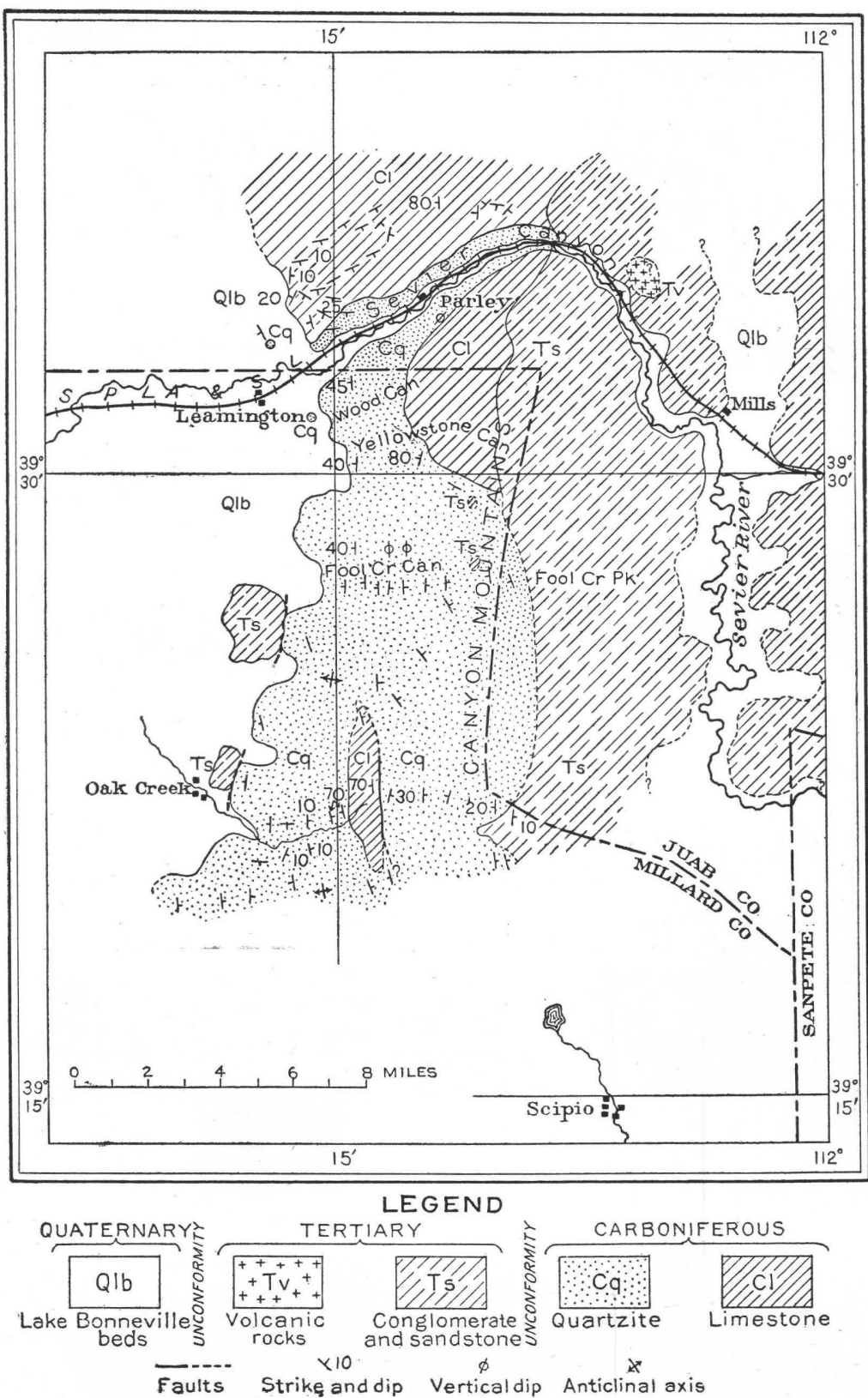

FIGURE 4.-Reconnaissance map of the Canyon Range, Utah, showing geologic formations.

broad in proportion to their lengths. Those on the east side were not seen at close range. Most of the lateral branches of the canyons on the west side are strike valleys separated by "hogback" ridges. (See fig. 5.) Some of these canyons are occupied by small creeks, the largest of which is Oak Creek, in the southern part of the range.

The most striking topographic feature is Sevier Canyon, in reality a rather wide valley with a flat bottom and gently sloping sides, which cuts completely across the range in a curved course at a very gentle gradient. Sevier River has terraced the unconsolidated lake deposits which constitute the canyon floor and follows a meandering course, interrupted at one or two places by gentle rapids, where it has uncovered buried ridges of quartzite.

\section{SETTLEMENTS.}

Two small agricultural towns are situated at the west base of the range at places where water for irrigation is available-Leamington, at the mouth of the canyon of Sevier River, and Oak Creek, or Oak City, at the mouth of Oak Creek canyon. A few ranches are located between these two towns, especially near the mouth of the canyon of Fool Creek, which supplies water for irrigation. The San Pedro, Los Angeles \& Salt Lake Railroad passes through Leamington and Sevier Canyon. Oak Creek is reached by stage from Leamington. 


\section{GEOLOGY.}

STRATIGRAPHY.

GENERAL FEATURES.

The Canyon Range is composed almost entirely of sedimentary rocks-Carboniferous limestone and quartzite overlain unconformably by Eocene conglomerate. Volcanic rocks have been reported from the extreme northern and southwestern parts of the range, beyond the limits of the area visited. The valleys on either side of the range are floored with beds of Pleistocene age that were deposited in Lake Bonneville and are known as Lake Bonneville beds, and locally with later alluvial deposits.

\section{SEDIMENTARY ROCKS.}

\section{CARBONIFEROUS LIMESTONE.}

The limestone, as shown on the map (fig. 4), is the prevailing rock northwest of Sevier Canyon and forms the middle western slope of the range south of Sevier Canyon as far as the south boundary of Yellowstone Canyon. North of Sevier Canyon it has generally low dips, associated with gentle anticlinal and synclinal flexures, but locally its beds stand nearly vertical. South of Sevier Canyon the dip varies from steep westerly to vertical. The limestone on both sides of Sevier Canyon dips beneath quartzite. A smaller limestone area extends north and south across Oak Creek. Its beds show a monoclinal structure, dipping $70^{\circ} \mathrm{W}$. beneath the quartzite and are sepa-

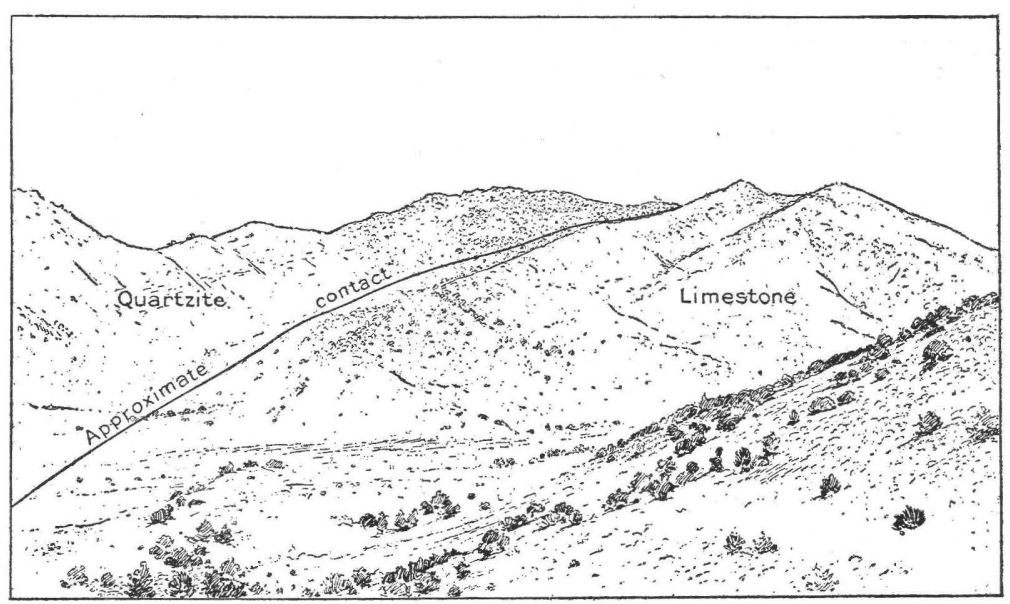

Figure 5.-View across North Fork of Yellowstone River, Canyon Range, Utah, looking northwest from Arbroath shaft.

rated on the east from quartzite by a strike fault. Limestone is also said to be exposed in the narrow southern part of the range, near Scipio. A lens of limestone in quartzite was noted on the north side of Fool Creek. This lies well above the main limestone formation.

The lithologic character of the limestone varies somewhat in different places. The lowest strata seen, about 3 miles northwest of Sevier Canyon, are thick to rather thin bedded, of medium to dark gray color, and fine to rather coarse grained in texture. Fossils are fairly abundant in certain beds. At a higher horizon, due north of Parley station, which is 5 miles northeast of Leamington, intercalated beds of shale are conspicuous. About a mile north of Parley station, on the east wall of a southward-sloping canyon, there is a prominent bluff of vertical strata which consists largely of conglomerate composed of limestone and chert pebbles and which lie within the zone of intercalated shale beds. The stratigraphic significance of this conglomerate can not be determined without detailed study, but from the paleontologic evidence (see p. 54) it appears to be only a local variation within a single limestone formation.

The uppermost limestone beds vary in character at different places. On the west slope of the range, northwest of Sevier Canyon, they are very cherty, nodules and continuous bands of chert comprising as much as 50 per cent of some beds. Perfect pseudomorphs of brachiopod shells are conspicuous in much of the chert. Shale beds at this place are not conspicuous, and the gradation from limestone upward into quartzite appears to be marked by increase in chert. The exact relations of the chert to the quartzite were not ascertained. 
In Wood Canyon the uppermost beds are of light to medium gray color and are dolomitic. Many of them are characterized by a concretionary or pisolitic structure, the concretions ranging up to an inch or more in diameter and offering greater resistance to weathering than the matrix. Above and intercalated with these strata are beds of striped shaly limestone, alternating with shale, and these in turn are overlain by a bed of brown ferruginous quartzite, which is followed by typical quartzite.

At no place is the entire thickness of the limestone exposed. A rough estimate of the exposed thickness northwest of Sevier Canyon gives 1,700 to 2,000 feet, but there are so many local variations in strike and dip that there are many chances for error in this estimate. The thickness of the limestone in Yellowstone Canyon is certainly much greater, but the entire exposed width was not studied, and the lower part of the limestone is concealed beneath thick bodies of Eocene conglomerate. In Oak Creek Canyon the exposed thickness is at least 3,500 and may be over 4,000 feet.

Fossils collected from the upper cherty limestone beds on the west slope of the range, $2 \frac{1}{2}$ to 3 miles northeast of Leamington station, were determined by G. H. Girty, of the United States Geological Survey, as follows:

Crinoid stems, large and numerous.

Zaphrentis sp.

Schuchertella chemungensis?

Schizophoria swallowi?

Spirifer centronatus.
Spirifer incertus?
Syringothyris carteri.
Cliothyridina aff. sublamellosa.

Another lot, collected at a horizon much lower stratigraphically, in the saddle between the two main ridges of the range, about $2 \frac{1}{2}$ miles north of Parley station, contains Spirifer centronatus and Composita humilis. Mr. Girty states that the first lot "is clearly of lower Mississippian or Madison facies," and that the second lot "is less diagnostic, since there are two Pennsylvanian species very similar to the only two comprised in the collection, but since the latter occurs below the first it must needs be Madison also." Fragments of fossils similar to those listed above were noted in Yellowstone Canyon in the upper part of the limestone.

The fossils prove the upper 1,700 to 2,000 feet of the limestone to be of lower Mississippian or Madison age. Lower portions may prove, on close study, to be older than Mississippian. In the Tintic district, 12 miles north of the Canyon Range, limestone of Mississippian age is 2,000 to 2,250 feet thick and is underlain by 4,400 to 4,600 feet of Cambrian and Ordovician limestone. In the southern Wasatch Mountains similar conditions are found, but only 2,400 or 2,500 feet of the older limestones are present. These two sections are the basis for the suggestion that the lower part of the limestone in the Canyon Range may be of pre-Mississippian age.

QUARTZITE.

The quartzite of the Canyon Range is exposed along the western half of Sevier Canyon and extends continuously southward well beyond Oak Creek. South of the divide between the Yellowstone and Fool Creek canyons the quartzite constitutes the summit and entire western slope of the range, with the exception of the faulted band of limestone (p. 53) across Oak Creek.

The quartzite as a rule is of fine, even grain and varies in color from nearly white to light and dark brown or reddish brown. Some of its beds are greenish. Its general appearance is very similar to that of the thick Cambrian quartzite exposed in the Tintic district and at several places along the Wasatch Range, thus accounting for the fact that the quartzite has heretofore been regarded as of Cambrian age.

The quartzite contains a conspicuous and persistent dark-reddish finely banded member, 400 or 500 feet thick, which is a convenient horizon marker and indicator of the geologic structure. (See figs. 6 and 7.) The northernmost exposure of this member is on the south side of Sevier Canyon, near its mouth, where it stands vertical in a pinched synclinal trough of southwesterly pitch. It was not traced southward across Wood and Yellowstone canyons 
but is undoubtedìy present in that part of the range. South of Yellowstone Canyon the red member follows the west edge of the range almost as far south as Fool Creek. It then swings southeast, crossing the lower part of Fool Creek canyon, and following an undulating course, probably passing north and east of Fool Creek Peak, the highest peak of the range. South of Fool Creek canyon the red member is probably present in the western part of the range, but was seen only in the vicinity of Oak Creek. North of Oak Creek canyon it is again prominent along the west edge of the range and is exposed in a very gentle anticline for a considerable distance along both walls of the canyon, from a point near its mouth to the first north branch. Here a sudden steepening of the easterly dip carries it below the surface, but it reappears about a mile farther up the canyon a short distance west of the limestone band. It again appears in the trough of a gentle syncline on the north slope of the canyon near its head. It was not followed south of Oak Creek canyon.
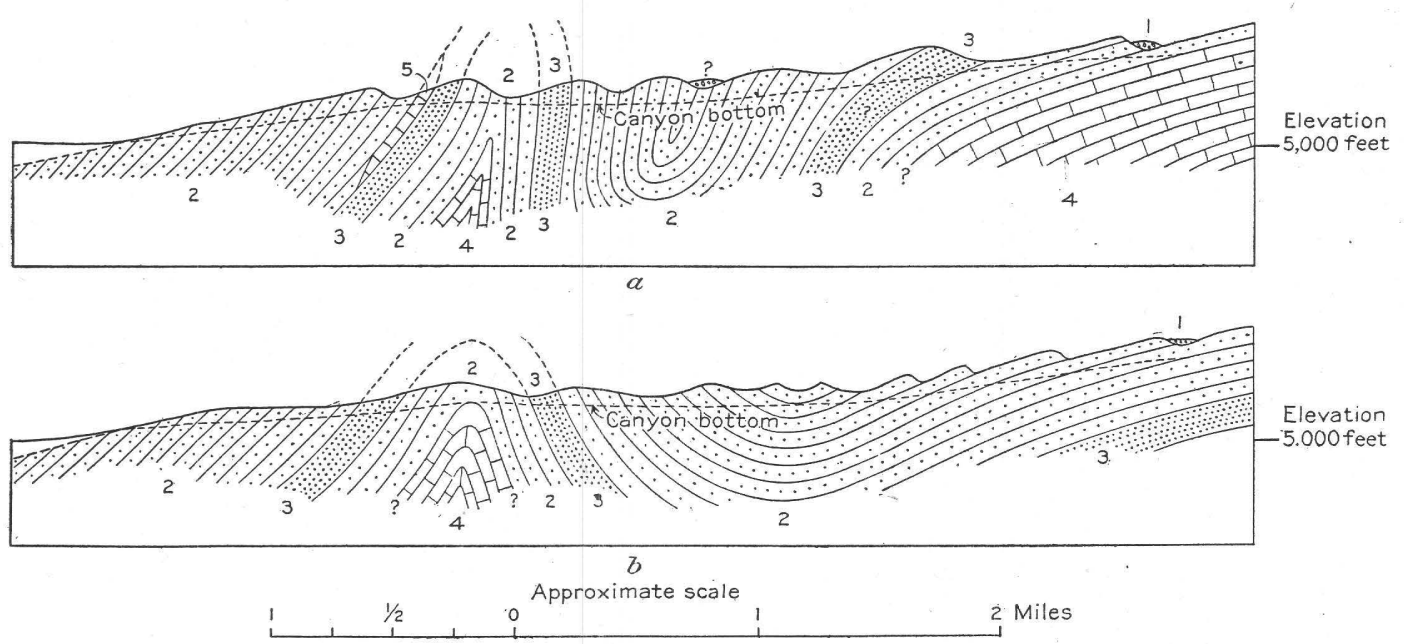

FIGURE 6.-Generalized section along north $(a)$ and south $(b)$ sides of Fool Creek canyon, Utah. 1, Tertiary conglomerate and sandstone; 2, Carboniferous quartzite; 3 , red member of the quartzite; 4, Carboniferous limestone; 5 , limestone lentil in quartzite.

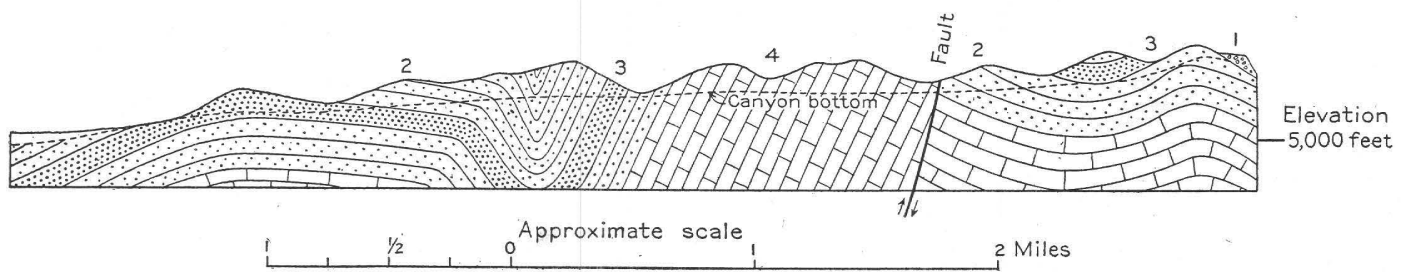

FIGURE 7.-Generalized section along north side of Oak Creek canyon, Utah. 1, Tertiary conglomerate and sandstone; 2, Carboniferous quartzite; 3 , red member of the quartzite; 4 , Carboniferous limestone.

One lens of gray limestone, mentioned on page 53, was noted on the north side of Fool Creek canyon. Detailed study may prove the presence of several such lenses.

The entire thickness of the quartzite was at no place exposed, owing to erosion of its upper portion. On the north side of Fool Creek canyon (fig. 6) the thickness of the exposed vertical strata on the east limb of the close anticline appears to be at least 5,000 feet. Elsewhere the variations in dip prevented a closer estimate.

No fossils were found in the quartzite, but its apparent conformable position above limestone of Madison age suggests that its lower part at least is Mississippian. Its upper part may be Pennsylvanian. A similar quartzite of great thickness, containing some limestone beds, forms the greater part of the West Tintic Mountains, the southern end of which is almost connected with the northwest end of the Canyon Range, and the writer has found upper Mississippian fossils in the limestone beds. Correlation, therefore, with this quartzite fixes the age of the quartzite of the Canyon Range as upper Mississippian. 
The upper Mississippian studied by the writer in the Tintic Mountains north of the Canyon Range and east of the West Tintic Range consists of a thick series of alternating limestone, shale, and sandstone or quartzite beds. The same series, 5,000 to 6,000 feet thick, is present in the southern part of the Oquirrh Range, ${ }^{1}$ and is overlain by the thick Bingham quartzite, which has been referred by Girty to the Pennsylvanian series. ${ }^{2}$ In the Wasatch Mountains the same intercalated series of limestones, shale, and sandstone is overlain by the Weber quartzite of Pennsylvanian age. These data indicate a transition northward and eastward from quartzite into strata composed largely of limestone and shale, and suggest that in late Mississippian and Pennsylvanian time the deposition of siliceous sediment was extended northward and eastward, overlapping the intercalated beds of limestone, shale, and sandstone.

EOCENE CONGLOMERATE.

The Eocene conglomerate is almost wholly confined to the east half of the range. A few small outliers were noted on the higher spurs north of Fool Creek, and their approximate posi-

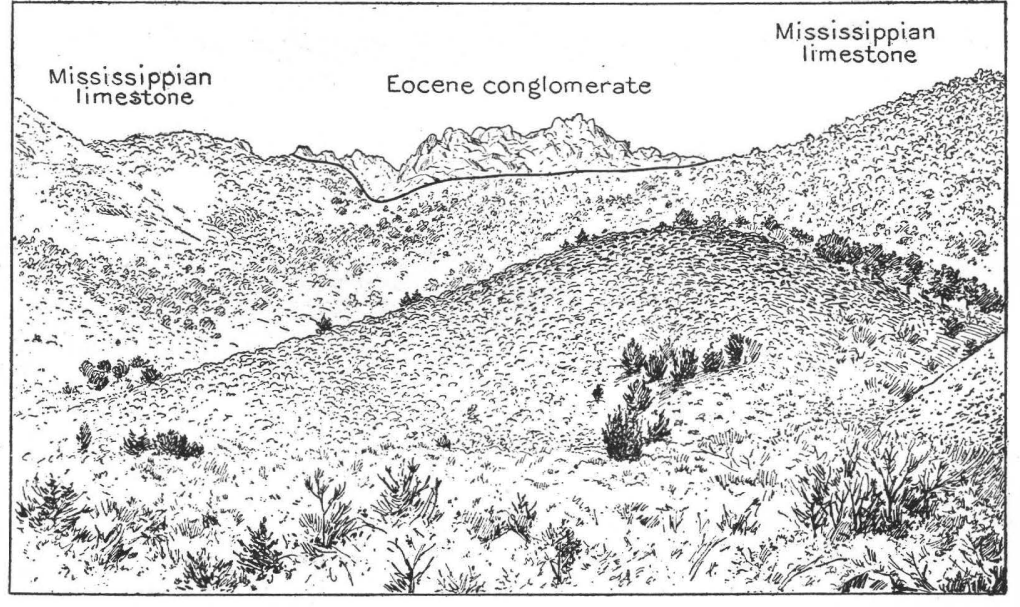

FIGURE 8.-Eocene conglomerate resting on upturned Mississippian (or older) limestone, at head of Yellowstone Canyon, Utah. tions are shown in figures 4 and 6. A considerable area, in which the rocks are very poorly exposed, was traversed along the low foothills north of the town of Oak Creek.

In the principal area the Eocene consists of light-gray and red beds of conglomerate and sandstone, the conglomerate pebbles including limestone, quartzite, and chert. The western boundary of the principal area is exposed in Sevier Canyon near its northernmost point, where a coarse conglomerate rests unconformably on quartzite. On both sides of the canyon the boundary can easily be seen from a distance, owing to the marked contrast in color between the younger and older formations. South of the canyon the Eocene beds rest on the upturned lower Mississippian limestone and form the crest and upper west slope of the range along the heads of Wood and Yellowstone canyons. (See fig. 8.) North of Fool Creek Peak the west boundary crosses the summit and extends along the eastern slope as far as the saddle at the head of Oak Creek canyon, where the contact is well exposed, the Eocene beds, with a dip of about $10^{\circ} \mathrm{E}$., abutting against a steep erosion surface of quartzite. This relation of dip to contact indicates a very uneven pre-Eocene topography.

The Eocene beds at the top of the saddle have disintegrated into loose cobbles and pebbles, with only scattered remnants of solid conglomerate. This disintegrated area lies between quartzite summits and is further indication of the unevenness of the Eocene topography.

The small outliers north and south of Fool Creek were recognized from a distance by their characteristic red color and by their rounded weathered surfaces, which sharply contrasted with the angular surfaces of the surrounding quartzite. The outliers occupied depressions between quartzite summits, suggesting that the basal portion of the Eocene conglomerate was deposited in strike valleys. (See fig. 6.) The existence of these pre-Eocene strike valleys at the heads of present strike valleys suggests that the present drainage is essentially the same as in pre-Eocene time, and may thus account for the shapes of the canyons, which, as already remarked (p. 52), are unusually broad in comparison to their lengths.

1 Spurr, J. E., Economic geology of the Mercur mining district, Utah: U. S. Geol. Survey, Sixteenth Ann. Rept., pt. 2, p. 377, 1896.

${ }^{2}$ Boutwell, J. M., Economic geology of the Bingham mining district, Utah: U. S. Geol. Survey Prof. Paper 38, appendix, p. 387 , 1905. 


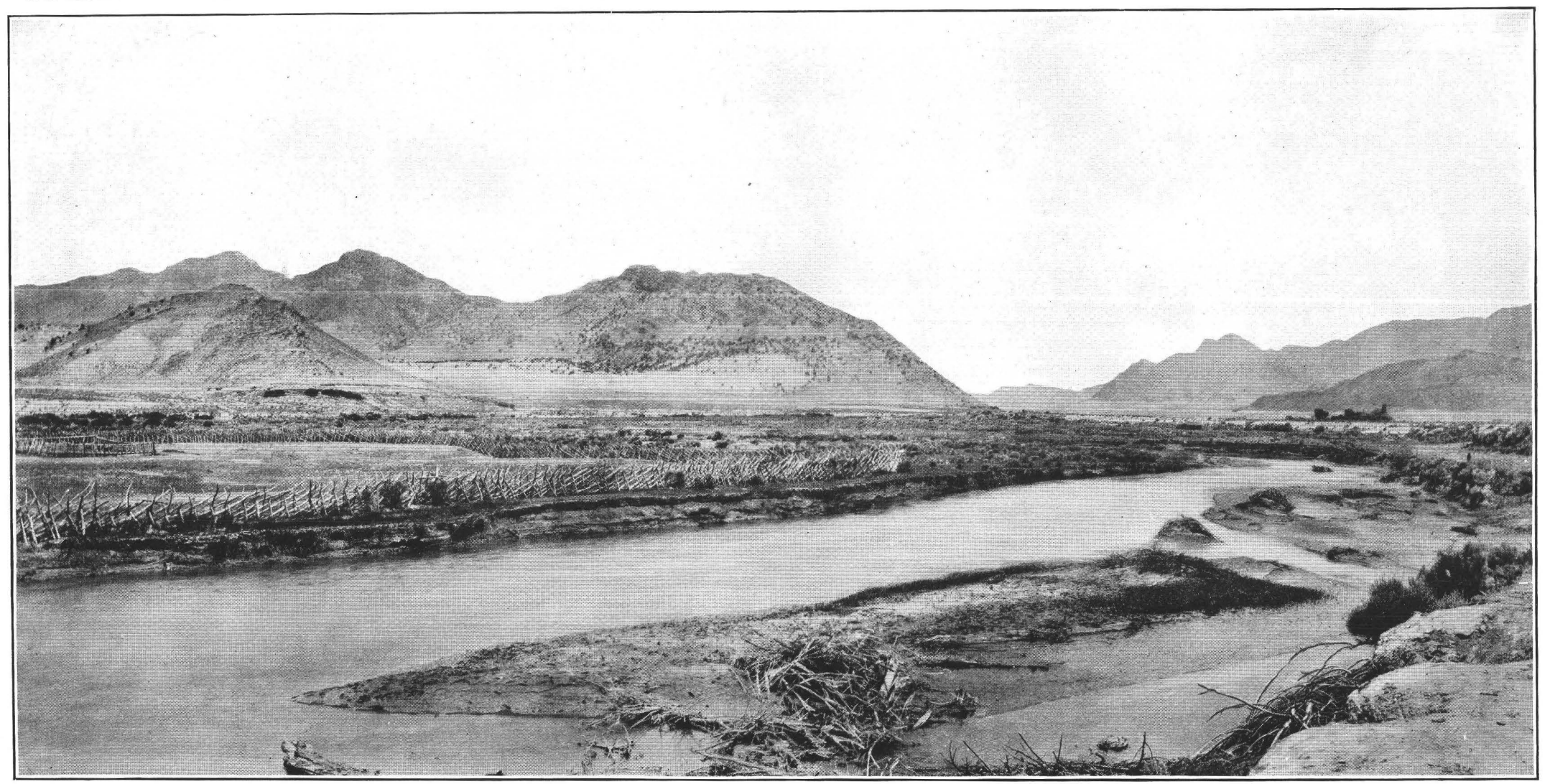

LAKE BONNEVILLE BEDS AT THE MOUTH OF SEVIER CANYON, NEAR LEAMINGTON, UTAH. 

The rocks which form the low foothills north of Oak Creek are almost completely reduced to a loose mass of limestone, quartzite, and chert cobbles, with a few remnants of consolidated conglomerate. These remnants furnish the clue to the origin of the foothills, which without them could not be explained, as the foothills are bounded on all sides by steep slopes and bear no direct relation whatever to the Quaternary alluvial deposits. The presence of the Eocene material in these deposits is presumably due to the sinking of a block during the faulting period when the Basin Ranges were developed. This occurrence extends the western boundary of Eocene deposition somewhat farther westward than has heretofore been indicated.

As only the eroded western edge of the Eocene beds was studied no idea of its thickness was gained. The beds are assigned to the Eocene by correlation with similar strata in the southern Wasatch Mountains ${ }^{1}$ and in the ranges immediately east of the Canyon Range. ${ }^{2}$

QUATERNARY DEPOSITS.

The Quaternary deposits include the Lake Bonneville beds of clay and marl deposited in Pleistocene time and the overlying alluvial deposits at the mouths of the canyons. The Lake Bonneville beds are terraced by Sevier River and are well exposed at Leamington and along the sides of Sevier Canyon, as shown in Plate IX. No special attention was given to these deposits by the writer, and the reader is referred for further information to Gilbert's monograph. ${ }^{3}$

\section{VOLCANIC ROCKS.}

No volcanic rocks were seen at close range. From a distance a bed of dark columnar volcanic rock was seen overlying Eocene beds northeast of the canyon, and its approximate location is shown in figure 6 . Volcanic rocks are said to be abundant in the extreme northern part of the range, and porphyry dikes are reported along Dry Canyon, south of Oak Creek. ${ }^{4}$

\section{STRUCTURE.}

The Carboniferous rocks are characterized by a few major folds with steep dips, by several intervening minor folds with gentle dips, and by a prominent strike fault which appears to be coincident with a broken anticline. The northernmost major fold is the unsymmetrical syncline of southwesterly pitch, whose axial plane is nearly parallel with the western half of Sevier Canyon. Its northwestern limb has a moderate dip, $25^{\circ}$ to $40^{\circ}$, which becomes lower away from the axis, passing into an area of prevailingly monoclinal structure, though the general low and regular inclination of the beds is interrupted by several inconspicuous anticlines and synclines. The southeast limb is nearly or quite vertical along Sevier Canyon, but along Wood and Yellowstone canyons its prevailing dip is near $45^{\circ}$.

In Fool Creek canyon an anticline and syncline with north-south axes are exposed. (See fig. 6.) On the north side the details of the structure are not very clear. The moderate westerly dip of the quartzite changes eastward to vertical, the latter persisting for about $1 \frac{1}{2}$ miles and then gradually changing to a moderate westerly dip, which continues eastward probably to the crest of the range. The only clue to the structure is given by the red quartzite member, aided by comparison with the simpler structure on the south side of the canyon, which shows the strata to be folded into a close anticline of vertical dip and an unsymmetrical syncline with vertical west limb and moderately dipping east limb. Detailed study, however, may show the vertical strata to be more complexly folded than figure 6 indicates. The structure on the south side of the canyon (fig. 6) needs no special comment. The lengths of these folds are not definitely known, but the anticline may extend as far north as the rim of the south fork of Yellowstone Canyon, where the uppermost limestone beds stand nearly vertical. That the limestone is probably not far below the surface where the anticline crosses Fool Creek may be inferred

${ }^{1}$ Loughlin, G. F., Jour. Geology, vol. 21, p. 448, 1913.

2 U. S. Geog. Surveys W. 100th Mer., atlas sheet 50.

3 Gilbert, G. K., Lake Bonneville: U. S. Geol. Survey Mon. 1, pp. 104, 166, 192, and 193, 1890.

4 Oral information by James Overson, of Leamington, Utah. 
by the proximity of the red member of the quartzite to the top of the limestone in Sevier and Oak Creek canyons.

Between Fool Creek and Oak Creek canyons several minor folds can be seen from the western foothills. In the lower part of Oak Creek canyon a gentle anticline with limbs dipping about $10^{\circ}$ is well exposed. About 2 miles above the mouth this passes into a syncline, both of whose limbs dip $60^{\circ}$ to $70^{\circ}$. The syncline, however, is not symmetrical. (See fig. 7.) The west limb is relatively small, but the east limb is at least $1 \frac{1}{2}$ miles in horizontal width and brings the limestone to the surface. The limestone is bounded on the east by the strike fault already mentioned, which separates it from quartzite of gentle easterly dip. The actual fault plane or zone is concealed; but the dips of the strata to either side of it north of the creek suggest a compression fault. (See fig. 7.) The fault appears to die out both southward and northward. Northward it appears to pass into an anticline whose axis is in the limestone; southward its relation to folding is not so clear, as the axes of the folds there swing southeastward and the trend of the fault is obscure. East of the fault the quartzite is folded into a rather gentle syncline and anticline, the anticlinal axis lying just east of the crest of the range.

The character of the folds show that in the central and southern parts of the range the dominant compressive force was eastward, whereas in the northern part the prevailing force was northwestward. No explanation of this difference in direction is warranted from so brief a study of this limited area.

\section{GEOLOGIC HISTORY.}

The geologic history of the Canyon Range may be summarized as follows: Deposition of limestone in early Mississippian and perhaps in still earlier time were followed by deposition of quartzite which continued during later Mississippian and possibly Pennsylvanian time. The next recorded event was the folding of these sediments, which presumably took place during the post-Jurassic upheaval that affected a great part of the Cordilleran region. The period of folding was followed by one of erosion, during which the rocks were dissected into ridges and valleys generally similar to those of to-day. The steep east slope along the southern part of the range, against which the Eocene strata are banked, was evidently formed at this time, and it is probable that a pronounced valley was developed in the Sevier Canyon syncline. Deposition during this erosion interval is represented by Cretaceous strata in the country to the south and east of the Canyon Range, and it is possible that the lowest beds called Eocene in the Canyon Range are Cretaceous. This deposition continued in the Eocene, during which the crest of the range was probably entirely covered by conglomerate and sandstone. The volcanic rocks were erupted in late Eocene or post-Eocene time.

The volcanic epoch was followed by the period of profound faulting in late Tertiary time which developed the Basin Ranges. One of these faults extends along the west base of the range, separating it from another block which moved downward and has left only its cap of disintegrated Eocene conglomerate above the present surface. A period of rapid erosion followed, during which all the Eocene strata were removed from the west side of the range save a few remnants which occupied the heads of old north-south valleys. During this combined period of uplift and erosion, Sevier River eroded its channel through the soft Eocene rocks fast enough to maintain its course. After it had worn through the Eocene strata which formerly existed on the west side of the present range its course was guided by the pronounced southwestpitching syncline, along which, as was just suggested, a valley may have existed in pre-Eocene time.

During a late stage in the erosion period, after the outline of the range was developed into virtually its present form, the surrounding lowlands were covered by the waters of Lake Bonneville, which at their highest (Bonneville) stage occupied Sevier Canyon and formed a landlocked bay on the east side of the range. It was in this stage that the fine material of the lake beds was deposited. Later, during the Provo stage of the lake, the waters lowered until they receded from the canyon, and Sevier River resumed its course, cutting its channel into 
the lake beds and building a low delta from Leamington southwestward to Deseret. Final recession of the lake waters left the topography essentially as it is to-day. The only noteworthy work of subsequent erosion was the further cutting of the Sevier channel through the newly formed delta.

\section{ORE DEPOSITS.}

Ore deposits thus far worked or prospected in the Canyon Range comprise only a few small bodies of lead or lead-zinc ore in Wood and Yellowstone canyons and some quartz veins stained with copper carbonates near Fool Creek and Dry canyons. Only two properties, so far as the writer has learned, have shipped ore.

\section{LEAD AND ZINC.}

Yellowstone mine.-The Yellowstone mine is located in the south fork of Yellowstone Canyon, about 4 miles southeast of Leamington. The workings include an inclined shaft 200 feet deep, following the dip of the limestone, about $60^{\circ} \mathrm{W}$., and drifts at the 50,100, and 170 foot levels. The country rock includes the uppermost beds of limestone. The ore forms small replacement bodies along the intersection of one of the limestone beds by fissures. On the 50-foot level small bodies were stoped along the intersection of the bed with a north-south strike fissure and one body where the bed was somewhat shattered at the intersection of the strike fissure and an east-west cross fissure. The 100 -foot level was inaccessible. The 170 -foot level follows the contact between a shale and limestone bed, along which there is a zone of veinlets, consisting chiefly of spar (dolomite and calcite), which are said to assay 3 to 4 per cent lead.

The ore stoped consisted principally of galena and cerusite (lead carbonate) in a gangue of ferruginous dolomite and calcite spar. A little secondary aragonite was noted on a crust of fibrous calcite that lined a pocket along the strike fissure on the 50-foot level. Assays of the ore have run from 30 to 65 per cent lead, the higher grade carrying 5 to 6 ounces of silver. A little gold has also been reported. The mine has been worked intermittently and has shipped only about 15 carloads of ore in over 20 years. No zinc has been found.

Arbroath mine.-The Arbroath shaft is situated about an eighth of a mile north of the Yellowstone, in a low spur which separates the south fork from the north fork of Yellowstone Canyon. The writer did not gain access to the mine, which was idle, but the material on the dump showed the mineralization to be of the same type as that of the Yellowstone mine. The ore thus far found during assessment work is reported to be of two grades, the higher carrying 76 per cent lead and 9 ounces silver, and the lower 10 to 11 per cent lead and 1 ounce silver. Only a small quantity of ore has been found thus far.

Wood Canyon group.- The Wood Canyon group of claims is situated on the north side of Wood Canyon and includes the uppermost beds of the limestone formation. The mineralized outcrop is a brown, rust-stained dolomitic bed, containing a large amount of ferruginous dolomite spar, white where fresh and brown where weathered, through which are scattered grains of galena and yellowish-brown zinc blende. The stained rock is closely associated with two fissures, one tending north-south and the other of S. $55^{\circ} \mathrm{E}$., both of whose outcrops are marked by shallow gulches. Plans for dry concentration of the ore were being considered in the summer of 1913. No assays, either of crude ore or concentrates, had been made.

\section{COPPER PROSPECTS.}

A small copper prospect in quartzite is situated on the low ridge just north of the mouth of Fool Creek canyon. The mineralized material thus far found is white vein quartz with numerous minute fractures stained by films of green and blue copper carbonates, with small spots and patches of dark brown iron oxide evidently derived through oxidation of pyrite and chalcopyrite.

Other copper and lead prospects have been reported along Dry Canyon, south of Oak Creek, but the writer's attempts to get in touch with the owners were not successful, and he could learn nothing further in regard to the deposits.

$$
37183^{\circ}-15-5
$$


COMPARISON WITH ORES OF OTHER DISTRICTS.

The lead and lead-zinc ores above described are similar in mineralogy and mode of occurrence to certain ores in the North Tintic, East Tintic, Santaquin, and Mount Nebo districts. These ores, which as a rule occur rather remote from important bodies of intrusive igneous rock, consist essentially of galena, zinc blende, and more or less pyrite, or oxidation products of these sulphides, with gangues of dolomite and calcite, and only minor amounts of quartz. Their silver content is low, averaging as a rule 3 to 5 ounces, but in some deposits rising as high as 8 to 10 ounces per ton. The sizes and shapes of ore bodies vary according to conditions; strong fissures may contain continuous veins; permeable beds of pure limestone may be rather extensively replaced; but argillaceous and dolomitic beds have yielded only small bodies of high-grade sre and a few more extensive bodies of milling ore. The ore bodies of the Canyon Range are no exception to this rule. Those mined up to the present have replaced dolomitic limestone beds along their intersections with narrow fissures and are small or of low grade. The highergrade ore bodies when found may be mined at no great expense, but the cost of prospecting for new bodies after old ones have become exhausted is likely to equal or exceed the net receipts from ore sales.

In some of the districts above named there are small copper prospects near the lead and zinc mines. These, according to the writer's experience, are quartz veins containing chalcopyrite and pyrite or their oxidation products and are confined to the siliceous rocks-quartzite, schist, or granite. The copper prospects of the Canyon Range may, from the meager knowledge available, be classed with this type. Veins intermediate in composition between these and the lead and zinc deposits have occasionally been found, and suggest that the two types were derived from a common source. None of these copper-bearing veins, to the writer's knowledge, have yielded steady shipments of ore. 